\title{
Multilevel governance and the coordination dilemma
}

\author{
Liesbet Hooghe and Gary Marks
}

\section{Introduction}

Multilevel governance (MLG), the dispersion of authority across scale, is both an increasingly salient observation and a stark dilemma. States are at the same time too large and too small to handle the problems that societies confront, from environmental degradation, ecosystem survival, failed states, and mass migration to human sustainability. Governance has become multilevel as regions within states have gained self-rule and authority has been pooled and delegated to international organizations (IOs). However, the most pressing problems require coordination across jurisdictions at diverse scales (Broschek and Lederer, Introduction, this volume). This generates a dilemma: MLG imposes the need for coordination, but it reduces the capacity of central governments to issue authoritative commands. In this chapter we argue that coordination in the absence of hierarchy rests on shared norms.

We proceed in five steps. In the next section we set out the distinctive logics of MLG and suggest that community as well as functional efficiency matter. We then use the theory of incomplete contracting to make the argument that shared norms facilitate coordination when hierarchy is in short supply. The third section examines this empirically for MLG among and within states. In the next two sections, we describe how shared norms can be harnessed to alleviate gaps in MLG, and how exclusive nationalism is the key challenge for negotiated MLG. 


\section{Two Logics}

Two logics underpin MLG. One is functionalist in that it conceives of governance as an instrument for the efficient provision of public goods. The second, no less powerful, logic is the demand for self-rule by those living in distinctive communities. Each of these logics has a rich literature, and while each has its proponents, we believe that they are most potent in combination.

The premise of the functionalist logic of multilevel governance is that each public good has an optimal spatial scale. The classic statement is Wallace Oates's $(1972 ; 2005)$ decentralization theorem that conceives a trade-off between scale economies and extra-regional externalities, which pull government up, and territorial heterogeneity of preferences, which pulls government down. Where the benefits and costs of providing a public good are spatially confined, as for parks or elementary schools, it is best to let local governments decide because they have better information about local tastes and conditions (Arrow 1991; Stein 2002). Conversely, where the public good has extensive economies of scale or wide-ranging externalities, as in health care, pensions, or financial regulation, national government should be responsible. The logic can be extended beyond the artificial ceiling of the national state. Combating highly infectious disease or facilitating international trade requires governance at the continental or global level. International institutions can be conceived as vehicles for reducing the transaction costs of interstate cooperation for large-scale public goods (Keohane 1984).

The optimal design is then to bundle policies in a limited number of widely spaced tiers of government (Hooghe and Marks 2009a). The result is a Russian Doll arrangement, where local governments are nested in regional governments, which are nested in national governments, and so on up to the globe as a whole. The overall pattern is unplanned and rather elegant, consisting of roughly equally spaced tiers at exponentially increasing population levels.

This comes into view when one maps the population of governance tiers in countries as diverse as China, Luxembourg, Argentina, and the United States. Figure 1.1 reveals a functionalist logic that maximizes scale flexibility while minimizing the number of jurisdictional tiers. The ladder of governance encompasses jurisdictions within, among, and beyond states in a local to global structure that is robust across countries with vastly different populations. Scale diversity appears to be an emergent phenomenon resulting from a vast number of micro decisions. 


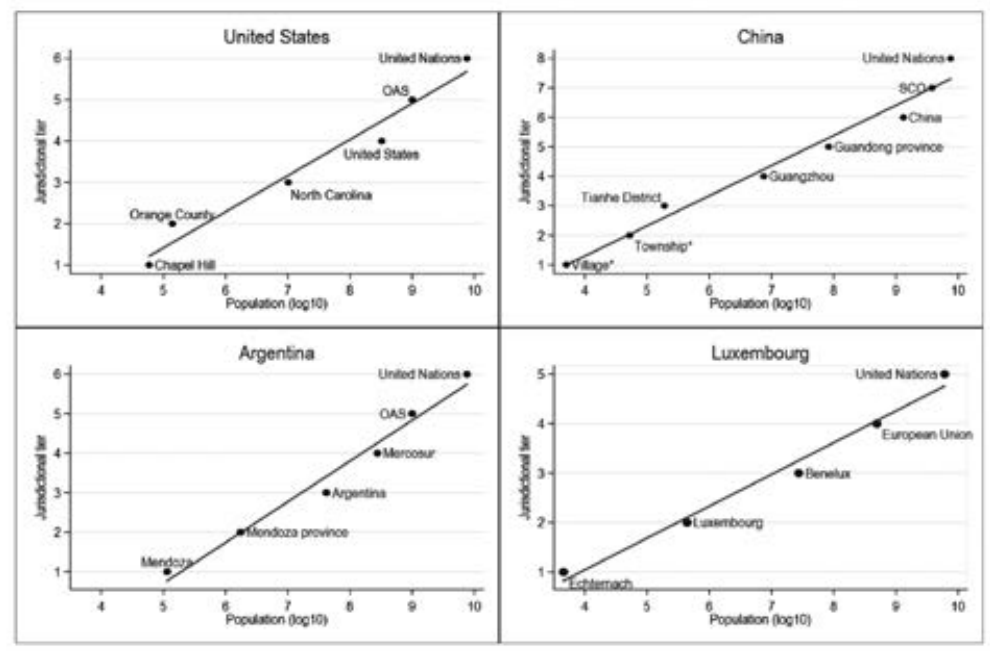

Note: Population estimates for 2010; population numbers for village and township in China are averages for the Tianhe district. OAS = Organization of American States; $\mathrm{SCO}=$ Shanghai Cooperation Organization.

Source: Hooghe and Marks (2009a).

\section{Figure 1.1 The ladder of governance}

However, functionalism is less adequate in explaining variation within this setup. To explain authority across tiers one must come to grips with the sociality of governance (Hooghe and Marks 2016). How do individuals conceive of the groups in which they live? Whereas functionalist explanations regard individuals as socially isolated beings, post-functionalist explanations give causal weight to the emotional attachments that individuals have to the societies of which they are part (Hooghe and Marks 2009b). The premise of a community logic is that preferences over governance are shaped by collective identity as well as policy preferences. Governance, in this approach, is an expression of community. The root of the modern concept of community is Aristotle's koinonia, or 'sharing in common' (Liddell and Scott 1940). Communities facilitate the provision of public goods because they nurture social networks, repeated interaction, and long time horizons that diminish free-riding. In Elinor Ostrom's (1990: 88) words, the capacity for providing public goods is enhanced where 'individuals have shared a past and expect to share a future'.

There are grounds for believing that the effect of community is double edged. Norms that facilitate governance within communities can constrain govern- 
ance among them. Communities are parochial to the extent that they divide the social world into insiders and outsiders, into 'us' and 'them'. Communities can be described as settings of parochial altruism, a combination of empathy with those within the group and antipathy to those attached to groups beyond (Bernhard, Fischbacher and Fehr 2006). Hence, a functionalist jurisdictional architecture may exist in tension with the political pressures resulting from the mobilization of community (Hooghe and Marks 2020; Kleider 2020). From a functionalist perspective, the optimal design is to bundle policies in a limited number of exponentially spaced tiers reflecting spatial externalities and economies of scale. From a community perspective, the structure of MLG will reflect the pattern of collective identities and the political struggle over whether they are conceived as inclusive or exclusive of overarching governance. This puts the spotlight on how identity is politicized. Exclusive territorial identities constrain MLG.

\section{Negotiated Governance}

The predominant fact about the ladder of governance is that it is not hierarchical. What can sustain governance when states are autonomous from IOs and when regions within states exert considerable self-rule? To understand governance under weak hierarchy we need to probe the conditions for voluntary cooperation. Two literatures-contract theory and game theory-engage this head-on. They converge in finding that cooperation in the provision of public goods depends on the sociality of the participants.

Governance in the absence of hierarchy rests on structured cooperation that specifies the responsibilities and commitments of the parties. Yet no contract for governance can nail down what is to be done in every possible contingency (Hooghe and Marks 2003; 2020). All contracting for governance is incomplete, yet the extent to which it is incomplete varies between task-specific governance and general-purpose governance.

Task-specific arrangements limit incompleteness by contracting governance narrowly around a clearly defined purpose, such as providing a particular local service, monitoring the water quality of a particular river, or adjudicating trade disputes. General-purpose arrangements, by contrast, bundle functions and responsibilities in an effort to deal flexibly with the problems that arise for a community. Whereas task-specific governance is concerned with problems 
that can be reasonably well specified in advance, general-purpose governance is open-textured and consequently more incomplete.

So the normative requisites of general-purpose governance are more demanding. The more incomplete the contract, the greater the importance of norms to guide actions in the 'spirit of the contract' (Hart and Moore 2008: 3). The participants must share priors about how to interpret the current contract and they must be committed to adapting the contract to changing conditions. The greater the scope for different perceptions of the same behaviour, the greater the importance of shared norms so that participants can identify mutual gains and negotiate ways to reap them. Shared norms extend the possibilities of cooperation by assuaging fears of exploitation and by promoting diffuse rather than specific reciprocity, key qualities for sustaining general-purpose governance.

Game-theoretic analysis of cooperation under incomplete information arrives at a similar conclusion. Game scenarios, such as iterated prisoners' dilemma, begin by assuming that the participants know exactly who the players are, what they can do, and what will result. The behaviour of all participants is transparent, now and in the past. As one relaxes these assumptions to approximate the 'games real actors play' (Scharpf 1994), the social requisites of cooperation come to the fore. What if the participants are unsure about what they will receive or how to estimate their benefits? What if they cannot be sure if others are really cooperating or just pretending to?

This provides the foundation for Fritz Scharpf's analysis of the 'negotiator's dilemma'. When cooperation is weakly informed, actors cannot tune their behaviour to the incentives given by a particular strategic scenario because, in Scharpf's (1994: 44-45) words, they 'would not be able to distinguish one game constellation from another'. In such situations, participants base their behaviour on 'generalized expectations' about what lies behind the behaviour of the other actors. Ostrom (2005: 106-107) speaks of shared mental maps; we denote this as the extent to which a group approximates a community.

Scharpf (1994: 46) cautions that, 'while generalised distrust is self-confirming, this is not true of generalized trust...Generalized trust presumes a willingness of partners to invest in the maintenance of a long-term cooperative relationship even at a cost to themselves in the individual case'. Where the shadow of hierarchy retreats, the possibilities for negotiated governance depend on the sociality of the participants. 


\section{Multilevel Governance and the Dilemma of Coordination}

Exclusive competence for any level of governance is a chimera. Decisions made by one government have effects for higher- or lower-level governments in the same territory and for neighbouring governments in the same tier. The effects of this can, in theory, be minimized by allocating competences in line with Herbert Simon's (1969) principle of near decomposability so that the short-run effects of each component subsystem are mostly self-contained. However, this is only a partial remedy. No jurisdiction is an island unto itself, and even the best jurisdictional designs are leaky. Containing climate change, mitigating the socio-economic impact of migration, and combating a pandemic are impossible to decompose in insulated policy packages. There is, in the words of George Frederickson (2004: 4), a 'mismatch or disconnect between jurisdictions on one hand and social, technological, political, and economic problems on the other hand'. Hence, a key challenge is to 'coordinate policies across boundaries of jurisdictions' (Benz 2019: 38; Bolleyer and Börzel 2010).

Two major developments have intensified the dilemma of coordination in MLG. Growing international interdependence has created problems that require cooperation in a non-hierarchical setting, that is, cooperation among national states. At the same time, hierarchy within national states has been weakened by regional and local self-rule. The problems we face require MLG; MLG requires coordination among autonomous actors.

\subsection{Coordination among states}

Some thirty-six IOs across the world are general purpose in that they deal with a wide range of problems that may affect connected peoples. The contracts undergirding these IOs are open-ended. They have indefinite scope and express the goal of overarching community: of 'creating an ever-closer union' (Treaty on European Union 2008: 16 [Preamble]); the desire to 'promote an ASEAN identity' (Association of Southeast Asian Nations Charter 2007: Art. 1.14); and forming 'an Andean subregional community' (Cartagena Agreement 1988: 1169 [Preamble]).

General-purpose IOs make explicit reference to common understandings, or 'shared mental maps', that facilitate convergent interpretation of behaviour and reduce the ambiguities of incomplete contracting (Hooghe, Lenz and 
Marks 2019a). Some general-purpose IOs are rooted in geographic proximity (e.g. the Pacific Community, the European Union, the Arab Gulf Cooperation Council); colonial history (the Commonwealth of Nations, the Francophone Community); religion (the Organization of Islamic Cooperation); or the struggle for national liberation (the Andean Community, the African Union).

The alternative is to contract cooperation narrowly so that states, no matter how diverse, can come together to solve a particular problem. By specifying the issue, task-specific governance minimizes fears arising from contractual incompleteness. For example, the World Health Organization (WHO) is focused on communicable disease; the International Civil Aviation Organization (ICAO) regulates civil aviation. Task-specific IOs are designed for problems that have global externalities and a correspondingly weak community basis.

These contrasting modes of governance are represented in Figure 1.2 by six leading IOs. The three at the top are general purpose. Their broad and imprecise purpose leads to greater institutional flexibility and, as a consequence, their policy competences and authority can grow quite rapidly over time. The three IOs at the bottom are task specific. They are grounded in less incomplete contracts and, correspondingly, their policy competences and authority are fixed at their foundation.

The Andean Community's portfolio grew from eleven policies in 1969 to nineteen by 2019, and now includes culture, education, and human rights. The $\mathrm{V}$-shaped discontinuity in delegation in the early 1980s represents the elimination in 1981 of the Latin American Free Trade Association (ALADI/LAFTA) dispute tribunal and its replacement in 1983 by the more authoritative Andean Court of Justice. ASEAN is sometimes described as an intergovernmental IO, but over time it has become more authoritative. Its portfolio grew from ten policies in 1968 to twenty-one in 2019. Expanding policy commitments have spurred states to enlarge the ASEAN secretariat, delegate agenda setting to the Secretary-General, and strengthen dispute settlement. The European Union, which started in 1952 with four policies, is today the only IO covering all twenty-five.

Each of these IOs can draw on shared norms to sustain cooperation. On a measure of transnational community that taps the extent to which the members of an IO share religion, culture, geographical location, political regime, and legal tradition, the Andean Community and the European Union rank among the most coherent general-purpose IOs, and ASEAN ranks among the least coherent (Hooghe, Lenz and Marks 2019a). However, even ASEAN 


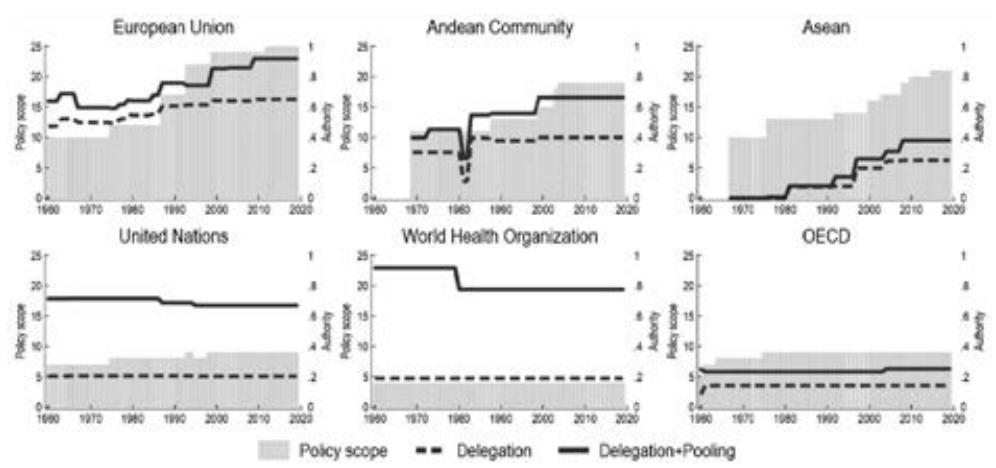

Note: $\quad 10$ authority is broken down into delegation, or authority that states collectively delegate to non-state international bodies; pooling, or shared decision-making among member states; and policy scope, or the number of policies for which an $1 \mathrm{O}$ is responsible. Delegation and pooling are estimated on a $0-1$ scale (right axis), and policy scope is estimated on a 1-25 scale (left axis). The dashed line tracks delegation, the solid black line tracks the sum of delegation and pooling, and the difference reflects pooling. The grey bars show policy scope.

Source: Hooghe et al. (2017); Hooghe, Lenz and Marks (2019a). The Measure of International Authority (MIA) is available from https://garymarks.web.unc.edu/data/ international-authority/.

Figure 1.2 Coordination among states: Delegation, pooling and policy scope in international organizations

member states affirm that they are 'bound by geography, common objectives and shared destiny' (ASEAN Charter 2007: Preamble).

As a general-purpose IO, the European Union is exceptional in depth and breadth. The past seventy years have seen a prolonged migration of authority to European institutions. No doubt the determination to avoid the catastrophe of repeated war motivated the experiment. Each of the original six member states had experienced foreign occupation and mass slaughter. However, European integration was rooted in deep commonalities as well as in the desire to overcome past hatreds. The conflicts that had plagued Europe-interstate rivalries, religious conflict, and finally total war-existed on a deeper bed of shared norms rooted in Christianity, the Renaissance, and sustained economic, social, intellectual, and cultural intercourse.

The European Union illustrates that the normative basis of cooperation is dynamic rather than fixed. Klingemann and Weldon (2013: 473) find that mutual trust among European Union populations has increased over time, and they speculate that political community can be 'learned...through, for example, memberships in professional associations, multinational businesses, educa- 
tional exchanges, tourism and the sharing of information through the media'. This is reinforced by studies of the effect of cross-border transactions (Kuhn 2015), educational exchange (Stoeckel 2016), and transnational marriage (Diez Medrano 2020) in deepening support for transnational governance. If so, the effect is generational: older people will be least affected, as revealed by their disproportionate support for Brexit (Sobolewska and Ford 2020).

The dynamism of general-purpose IOs contrasts with the stasis exhibited by task-specific IOs. The World Health Organization (WHO) and the Organisation for Economic Co-operation and Development (OECD) at the bottom of Figure 1.2 are examples of cooperation among extremely diverse states. Their trick is to specify a relatively complete contract to deal with a specific problem. They assure their members that they can provide effective governance on a narrow front while avoiding nasty surprises. The policy problem, rather than the collective nature of the participants, determines membership.

The United Nations stands alone as a global IO with an ambition to be general purpose. This produces strains because its members are so diverse, but the UN has ingeniously found ways to reduce the uncertainty arising from its relatively open-ended contract. The UN has reserved its authority for matters of peace and security and gives its most powerful members veto rights; it decentralizes decision-making to more cohesive regional groupings of members; and it farms out the bulk of global governance to task-specific IOs, such as the WHO.

General-purpose IOs and task-specific IOs are distinct responses to the dilemma of international coordination: how to achieve scale in the absence of thick community. The answer from general-purpose governance is to build cooperation on existing community even if this is thin compared to that within states. The answer on the part of task-specific governance is to focus on a discrete problem that can be narrowly contracted.

\subsection{Coordination within states}

The growth in MLG within states since World War II amounts to a quiet revolution. It is quiet because it is rarely constitutionalized and almost never catapults countries into full-blooded federalism. In Europe, just one countryBelgium-has become federal, and worldwide the number of countries that have crossed the federal-unitary boundary can be counted on the fingers of one hand. Yet MLG has deepened in almost every non-federal country that is middle-sized or larger. 
Figure 1.3 plots regional authority in 95 countries from 1950 to 2018. The estimates come from the Regional Authority Index (RAI), which breaks regional authority down into self-rule, the authority exercised by a regional government over those who live in the region, and shared rule, the authority exercised by a regional government or its representatives in the country as a whole (Hooghe et al. 2016; Shair-Rosenfield et al. 2021). The contrast across the first three panels makes the point that regional authority in non-federal countries is sensitive to the scale of a country's population. Non-federal countries with a population of less than 10 million have minimal governance between the local and the national; those with populations of 10 million-50 million have moderately authoritative regional governance; and those with populations greater than 50 million have substantial regional governance. The association between the $\log$ of population and the RAI for non-federal countries is 0.71 . This reflects powerful functionalist pressures to adapt the structure of governance to the benefits of scale diversity in public goods provision. In contrast, federalism is a political choice that bears little relation to the population of a country: the bivariate association between population and the RAI is 0.04 .

Figure 1.3 also reveals a marked difference in the composition of regional authority. Federal countries have, by far, the highest levels of shared rule; non-federal countries have very little. Shared rule in federal countries averages 4.8 in 1950 , rising to 7.8 in $2018 .{ }^{1}$ In non-federal countries with a population greater than 10 million, the index for shared rule is just 1.1 in 1950 and 1.5 in 2018. The distinctive characteristic of federalism is the decision to involve constituent regions in co-governing the country as a whole, which is the chief instrument for institutionalizing coordination between multiple tiers of government.

Increases in regional authority in non-federal countries have been almost exclusively in self-rule. The RAI of countries with a population in excess of 10 million has almost doubled since 1950, from 6.3 to 12.5 , and 94 per cent of this increase has been self-rule. MLG has also produced multilevel democracy (Tatham, Chapter 8, this volume; Piattoni and Schönlau 2015). Nineteen of twenty-seven European Union countries now have direct elections for regional assemblies, while just four countries did so in 1979. Today every European country with a population greater than 10 million has regional elections (Schakel 2018: 687). The rise in self-rule has been particularly steep for distinctive territorial communities, from Aceh (Indonesia) to Wales (UK), as well as for Indigenous Communities across Latin America. Except for Belgium, where the central government sought to tie regions into national decision-making through federalism, shared rule has grown only modestly. 

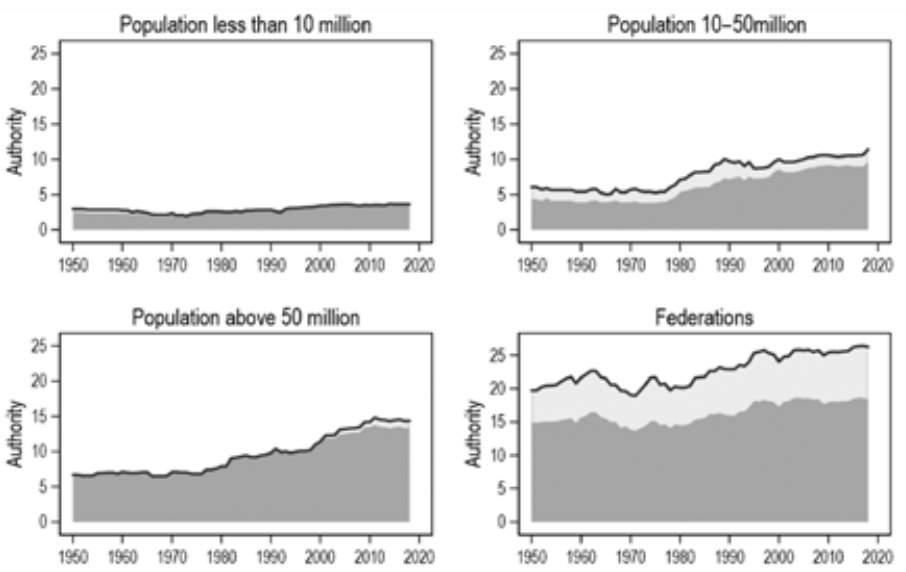

shared rule self-rule Regional authority

Note: Self-rule is the authority exercised by a regional government over those who live in the region, and shared rule is the authority exercised by a regional government or its representatives in the country as a whole. The sample includes ninety-five countries from 1950 to 2018 (forty-five with small populations, twenty-one with 10-50 million people, thirteen with more than 50 million, and sixteen federations in 2018). A regional tier's authority can range between one and thirty, summed across ten dimensions. Regional scores are aggregated to country scores, and these are averaged in each panel.

Source: Hooghe et al. (2016); Shair-Rosenfield et al. (2021). The Regional Authority Index (RAI) is available from https://garymarks.web.unc.edu/data/regional-authority/

Figure 1.3 Coordination within states: Self-rule and shared rule for regional governments

In all but the smallest countries, there has been a sustained dispersion of decision-making away from the central state. Deeper regional self-rule has punctured the notion that central states can coordinate by command (Hooghe, Marks and Schakel, 2020; Tatham and Bauer 2021). This is not a move to federalism: shared rule that ties individual regions into policymaking for the country as a whole has not kept pace. This raises, in sharp form, the challenge of coordinating relatively autonomous actors. 


\section{Incentivizing Coordination Under the Shadow of Community}

MLG has intensified concern about interjurisdictional blockage, a problem that the OECD has taken up in its effort to improve policymaking in its member states. The OECD's point of departure is that 'MLG has become an imperative rather than a theoretical option to respond to a much more complex and networked system of interactions among stakeholders in the design and implementation of public policies' (Allain-Dupré 2020: 803-804). However, the fear is that MLG may exacerbate, rather than solve, the challenge of policy complexity. Extending self-rule to local and regional governments can lead to 'governance gaps', interjurisdictional conflict, and mismanagement (OECD 2018b). In response, the OECD's Regional Development Policy Committee has come up with an 'MLG tool' to improve interjurisdictional coordination in three steps: (a) map the competences and interaction of the key stakeholders; (b) diagnose 'gaps' in coordination; and (c) propose remedies (Charbit 2011; OECD 2018a).

One remedy highlighted by the OECD is contracting among stakeholders as a means to reduce uncertainty and facilitate negotiated governance (Charbit 2020). These contracts can be transactional or relational; they may devolve, or merely conditionally delegate, competences; and some may introduce a measure of shared rule to temper the fissiparous consequences of self-rule.

A best-practice example is the 'Amsterdam Approach' to the integration of migrants and asylum seekers. At its core is an 'early integration response' led by an interdepartmental team of civil servants with the authority to negotiate contracts with the central government, local agencies, and key civil society groups to provide language courses, health access, and a path to employment (OECD 2018b: 35). The centrepiece is a convenant, 'Amsterdam werkt voor iedereen', 2 involving custom-tailored contracts with large employers, non-governmental organizations (NGOs), and local, provincial, and national stakeholders (Gemeente Amsterdam n.d.). Amsterdam has a long tradition of migrant hospitality, but even when most stakeholders share diffuse policy goals, the OECD argues that contracts improve coordination by clarifying expectations and responsibilities.

Such contracts are most effective when the participants have a normative commitment not to exploit the others in the room. The policy problems that are on the table tend to be wicked (i.e. they involve ambiguity and a corresponding 
potential for free-riding; Rittel and Webber 1973). It is not sufficient to believe that one can enforce the letter of the contract if the contract is always going to be opaque when applied to unforeseen events. Incomplete contracting relies on priors about its interpretation, on shared norms that help the participants identify mutual gains and provide reassurance they will not be cheated. As the shadow of hierarchy recedes, so negotiated governance among autonomous actors relies on shared mental maps and diffuse reciprocity (i.e. community).

\section{Nationalism and Multilevel Governance}

MLG works best when the participants feel that they can fairly share rule, that they will not be exploited by those with different norms. However, shared rule, for all its benefits, inevitably limits the self-rule of participating groups. And the desire for self-rule can be one of the most powerful motivations in politics. That is why MLG can be extremely contentious. Democracy is no panacea. The question of which group should have a capacity for self-rule is prior to the question of how a group should make decisions. Hence, MLG involves potential conflict that cannot be settled by majority rule. Who should have the right to make collectively binding decisions? Who is included and who excluded from membership of the community?

MLG is a functional adaptation to scale diversity in the provision of public goods, yet it rests on some form of overarching attachment to communities at different territorial scales-to feel both Flemish and Belgian, Belgian and European, or English and British, British and European. The affinities and tensions in these attachments provide a key, we argue, to the possibilities of general-purpose governance at multiple scales. The sources of such identities are framed and contested in the history and politics of a society (Diez Medrano 2000; Risse 2010; Zuber 2021).

At a time when many feel left behind by forces that have diminished the protective capacity of the state, identities in Western societies have been mobilized in conflict about transnationalism. At the exclusionary pole are those who want to defend their way of life against external actors who penetrate their community by migrating, exchanging goods, or exerting rule. At the inclusive pole are those who conceive their identity as enhanced by MLG and who welcome, rather than oppose, the interpenetration of societies (Hooghe and Marks 2018; Hutter, Grande and Kriesi 2016). 
Exclusive nationalism can squeeze MLG above and below the state. Populist nationalists may try to stop migration, constrain international organization, and limit trade (De Wilde et al. 2019; Hooghe, Lenz and Marks 2019b). State nationalists may exacerbate demands for exclusive self-rule on the part of regionalists (Cétra and Swenden 2021; Toubeau 2018). And exclusive regionalists may oppose supranational alongside national governance on the ground that both undermine sovereignty (Massetti and Schakel 2021).

However, support for MLG remains broadly based, and it is predominant among political and economic elites (Strijbis, Teney and Helbling 2019; Verhaegen, Scholte and Tallberg 2021). Support for MLG is particularly strong at the regional level. A survey of regional elites in twelve European countries reveals a clear preference for sharing policy responsibilities across regional, national, and European governments (Tatham and Bauer 2021). Tellingly, the dominant narrative in the mass media continues to be told by a 'globalist coalition campaigning for open borders... and favour[ing] free trade and regional integration' (De Wilde 2019: 101). Surveys find majority backing for international governance that tempers national sovereignty in providing security and environmental policy (Cavatorto, Cotta and Russo 2020; Strijbis, Teney and Helbling 2019).

The rise of TAN (traditional-authoritarian-nationalist) political parties has thrust MLG into polarized debate, but it has not displaced it. The expansion of MLG has coincided with an extended period of peace among the major powers, liberal democracy, and a sustained growth of tertiary education. These have proven to be mutually reinforcing developments that underpin international and subnational governance (Marks et al. 2020). The absence of war among the major powers has opened space for deep and broad international cooperation. Liberal democracy underpins both support for international organization and for subnational empowerment. Access to higher education has diluted parochial attachments and swelled the ranks of people who feel at home in a more fluid, diverse, cosmopolitan society. There is also the subtle but pervasive effect of MLG in facilitating the provision of public goods, including economic exchange and knowledge.

However, to say that MLG rests ultimately on avoiding major international conflict and authoritarianism is to raise the possibility that it can be stopped or even turned back. What if authoritarianism were to deepen its grip in Russia, China, Brazil, and India, or make serious inroads in the West? What if the Second Cold War that is currently underway between China and the United States turns hot? There is nothing inevitable about the developments we have charted in this essay. MLG is vulnerable to both geopolitics and regime change. 


\section{NOTES}

1. A regional tier or region can collect a maximum of twelve points for shared rule on the RAI scale.

2. Amsterdam works for everybody.

\section{References}

Allain-Dupré, Dorothée (2020), 'The Multi-Level Governance Imperative', British Journal of Politics and International Relations, 22 (4), 800-808.

Arrow, Kenneth J. (1991), 'Scale Returns in Communication and Elite Control of Organizations', Journal of Law, Economics, and Organization, 7, 1-6.

ASEAN Charter (2007), 'Charter of the Association of Southeast Asian Nations', November 2007, accessed 10 May 2021, https://asean.org/wp-content/uploads/ images/archive/21069.pdf.

Benz, Arthur (2019), 'Transformation of the State and Multilevel Governance', in Nathalie Behnke, Jörg Broschek and Jared Sonnicksen (eds.), Configurations, Dynamics and Mechanisms of Multilevel Governance, Cham: Springer International, pp. 23-40.

Bernhard, Helen, Urs Fischbacher and Ernest Fehr (2006), 'Parochial Altruism in Humans', Nature, 442 (7105), 912-915.

Bolleyer, Nicole and Tanja A. Börzel (2010), 'Non-Hierarchical Policy Coordination in Multilevel Systems', European Political Science Review, 2 (2), 157-185.

Cartagena Agreement (1988), 'Andean Pact: Official Codified Text of the Cartagena Agreement Incorporating the Quito Protocol', 25 May 1988, International Legal Materials, 28 (5), 1165-1211, accessed 10 May 2021, http://doi.org/10.1017/ S002078290002266X.

Cavatorto, Sabrina, Maurizio Cotta and Federico Russo (2020), 'When the Going Gets Tough: Who Should Take Responsibility in Times of Crisis - European or National Institutions?', in Maurizio Cotta and Pierangelo Isernia (eds.), The EU Through Multiple Crises, London: Routledge, pp. 133-157.

Cétra, Daniel and Wilfried Swenden (2021), 'State Nationalism and Territorial Accommodation in Spain and India', Regional and Federal Studies, 31 (1), 115-137.

Charbit, Claire (2011), 'Governance of Public Policies in Decentralised Contexts: The Multi-Level Approach', OECD Regional Development Working Papers, 2011/04. Paris: OECD Publishing.

Charbit, Claire (2020), 'From "de jure" to "de facto" Decentralised Public Policies: The Multi-Level Governance Approach', British Journal of Politics and International Relations, 22 (4), 809-819.

De Wilde, Pieter (2019), 'Mapping Policy and Polity Contestation About Globalization: Issue Linkage in the News', in Pieter De Wilde, Ruud Koopmans, Wolfgang Merkel, Oliver Strijbis and Michael Zürn (eds.), The Struggle Over Borders: Cosmopolitanism and Communitarianism, Cambridge, UK: Cambridge University Press, pp. 89-115.

De Wilde, Pieter, Ruud Koopmans, Wolfgang Merkel, Oliver Strijbis and Michael Zürn (eds.) (2019), The Struggle Over Borders: Cosmopolitanism and Communitarianism, Cambridge, UK: Cambridge University Press. 
Diez Medrano, Juan (2000), Framing Europe: Attitudes to European Integration in Germany, Spain, and the United Kingdom, Princeton, NJ: Princeton University Press.

Diez Medrano, Juan (2020), Europe in Love: Binational Couples and Cosmopolitan Society, London: Routledge.

Frederickson, H. George (2004), 'Whatever Happened to Public Administration? Governance, Governance Everywhere', Institute of Governance, Public Policy and Social Research Working Paper QU/GOV/3/2004. Belfast: Queen's University.

Gemeente Amsterdam (n.d.), 'Convenant Amsterdam Werkt voor Iedereen', accessed 10 May 2021, https://www.amsterdam.nl/bestuur-organisatie/volg-beleid/werk -participatie/participatie/.

Hart, Oliver and John Moore (2008), 'Contracts as Reference Points', Quarterly Journal of Economics, 123 (1), 1-48.

Hooghe, Liesbet, Tobias Lenz and Gary Marks (2019a), A Theory of International Organization, Oxford: Oxford University Press.

Hooghe, Liesbet, Tobias Lenz and Gary Marks (2019b), 'Contested World Order: The Delegitimation of International Governance', Review of International Organizations, 14 (4), 731-743.

Hooghe, Liesbet and Gary Marks (2003), 'Unraveling the Central State, but How? Types of Multilevel Governance', American Political Science Review, 97 (2), 233-243.

Hooghe, Liesbet and Gary Marks (2009a), 'Efficiency and the Territorial Structure of Government', Annual Review of Political Science, 12 (May), 225-241.

Hooghe, Liesbet and Gary Marks (2009b), 'A Postfunctionalist Theory of European Integration: From Permissive Consensus to Constraining Dissensus', British Journal of Political Science, 39 (1), 1-23.

Hooghe, Liesbet and Gary Marks (2016), Community, Scale, and Regional Governance, Oxford: Oxford University Press.

Hooghe, Liesbet and Gary Marks (2018), 'Cleavage Theory and Europe's Crises: Lipset, Rokkan and the Transnational Cleavage', Journal of European Public Policy, 25 (1), 109-135.

Hooghe, Liesbet and Gary Marks (2020), 'A Postfunctionalist Theory of Multilevel Governance', British Journal of Politics and International Relations, 22 (4), 820-826.

Hooghe, Liesbet, Gary Marks and Arjan H. Schakel (2020), 'Multilevel Governance', in Daniele Caramani (ed.), Comparative Politics, Oxford: Oxford University Press, pp. 193-210.

Hooghe, Liesbet, Gary Marks, Tobias Lenz, Jeanine Bezuijen, Besir Ceka and Svet Derderyan (2017), Measuring International Authority. A Postfunctionalist Theory of Governance, Volume III, Oxford: Oxford University Press.

Hooghe, Liesbet, Gary Marks, Arjan H. Schakel, Sara Niedzwiecki, Sandra Chapman Osterkatz and Sarah Shair-Rosenfield (2016), Measuring Regional Authority: A Postfunctionalist Theory of Governance, Oxford: Oxford University Press.

Hutter, Swen, Edgar Grande and Hanspeter Kriesi (eds.) (2016), Politicising Europe: Mass Politics and Integration, Cambridge, UK: Cambridge University Press.

Keohane, Robert O. (1984), After Hegemony: Cooperation and Discord in the World Political Economy, Princeton, NJ: Princeton University Press.

Kleider, Hanna (2020), 'Multilevel Governance: Identity, Political Contestation, and Policy', British Journal of Politics and International Relations, 22 (4), 792-799.

Klingemann, Hans-Dieter and Steve Weldon (2013), 'A Crisis of Integration? The Development of Transnational Dyadic Trust in the European Union, 1954-2004', European Journal of Political Research, 52 (4), 457-482. 
Kuhn, Theresa (2015), Experiencing European Integration. Transnational Lives and European Identity, Oxford: Oxford University Press.

Liddell, George and Robert Scott (1940), A Greek-English Lexicon, Oxford: Clarendon Press.

Marks, Gary, David Attewell, Jan Rovny and Liesbet Hooghe (2020), 'The Changing Political Landscape in Europe', in Maurizio Cotta and Pierangelo Isernia (eds.), The EU Through Multiple Crises, London: Routledge, pp. 20-44.

Massetti, Emanuele and Arjan H. Schakel (2021), 'From Staunch Supporters to Critical Observers: Explaining the Turn Towards Euroscepticism Among Regionalist Parties', European Union Politics, 1-22, accessed 10 May 2021, https://doi.org/10 $.1177 / 14651165211001508$.

Oates, Wallace E. (1972), Fiscal Federalism, New York, NY: Harcourt Brace Jovanovich.

Oates, Wallace E. (2005), 'Toward a Second-Generation Theory of Fiscal Federalism', International Tax and Public Finance, 12 (4), 349-373.

OECD (2018a), Working Together for Local Integration of Migrants and Refugees, Paris: OECD Publishing.

OECD (2018b), Working Together for Local Integration of Migrants and Refugees in Amsterdam, Paris: OECD Publishing.

Ostrom, Elinor (1990), Governing the Commons. The Evolution of Institutions for Collective Action, Cambridge, UK: Cambridge University Press.

Ostrom, Elinor (2005), Understanding Institutional Diversity, Princeton, NJ: Princeton University Press.

Piattoni, Simone and Justus Schönlau (2015), Shaping EU Policy from Below: EU Democracy and the Committee of the Regions, Cheltenham, UK and Northampton, MA: Edward Elgar Publishing.

Risse, Thomas (2010), A Community of Europeans? Transnational Identities and Public Spheres, Ithaca, NY: Cornell University Press.

Rittel, Horst W. and Melvin M. Webber (1973), 'Dilemmas in a General Theory of Planning', Policy Sciences, 4 (2), 155-169.

Schakel, Arjan H. (2018), 'Rethinking European Elections: The Importance of Regional Spill-Over Into the European Electoral Arena', Journal of Common Market Studies, 56 (3), 687-705.

Scharpf, Fritz W. (1994), 'Games Real Actors Could Play: Positive and Negative Coordination in Embedded Negotiations', Journal of Theoretical Politics, 6 (1), 27-53.

Shair-Rosenfield, Sarah, Arjan H. Schakel, Sara Niedzwiecki, Gary Marks, Liesbet Hooghe and Sandra Chapman Osterkatz (2021), 'Language Difference and Regional Authority', Regional and Federal Studies, 31 (1), 73-97.

Simon, Herbert (1969), The Sciences of the Artificial, Cambridge, MA: MIT Press.

Sobolewska, Maria and Robert Ford (2020), Brexitland, Cambridge, UK: Cambridge University Press.

Stein, Jeremy C. (2002), 'Information Production and Capital Allocation: Decentralized vs. Hierarchical Firms', Journal of Finance, 57 (5), 1891-1921.

Stoeckel, Florian (2016), 'Contact and Community: The Role of Social Interactions for a Political Identity', Political Psychology, 37 (3), 431-442.

Strijbis, Oliver, Celine Teney and Marc Helbling (2019), 'Why Are Elites More Cosmopolitan than Masses?', in Pieter De Wilde, Ruud Koopmans, Wolfgang Merkel, Oliver Strijbis and Michael Zürn (eds.), The Struggle Over Borders: Cosmopolitanism and Communitarianism, Cambridge, UK: Cambridge University Press, pp. 37-64. 
Tatham, Michaël and Michael W. Bauer (2021), 'Hungry for Power? Regional Elites and the Architecture of Government', Governance, 34 (3), 621-642.

Toubeau, Simon (2018), 'Restructuring the State: Mainstream Responses to Regional Nationalism', Publius, 48 (1), 76-101.

Treaty on European Union (2008), 'Consolidated Versions of the Treaty on European Union', Official Journal of the European Union C115, 51 (9), 1-45, accessed 10 May 2021, https://eur-lex.europa.eu/legal-content/EN/TXT/?uri=OJ:C:2008:115:TOC.

Verhaegen, Soetkin, Jan Aart Scholte and Jonas Tallberg (2021), 'Explaining Elite Perceptions of Legitimacy in Global Governance', European Journal of International Relations, accessed 20 May 2021, https://doi.org/10.1177/1354066121994320.

Zuber, Christina (2021), Past Incentives, Present Choices: Ideational Legacies and the Politics of Migration in European Minority Regions, Oxford: Oxford University Press. 